\title{
EVAULATION OF THE QUALITY OF AN AQUATIC HABITAT ON THE DRIETOMICA RIVER
}

\author{
Ivan STANKOCI ${ }^{1}$, Jana JARIABKOVÁ ${ }^{1}$, Viliam MACURA ${ }^{1}$
}

\section{Abstract}

The ecological status of a river is influenced by many factors, of which the most important are fauna and flora; in this paper they are defined as a habitat. During the years 2004, 2005, 2006 and 2011, research on the hydroecological quality of a habitat was evaluated in the reference section of the Drietomica River. Drietomica is a typical representative river of the Slovak flysch area and is located in the region of the White Carpathians in the northwestern part of Slovakia. In this article the results of modeling a microhabitat by means of the Instream Flow Incremental Methodology (IFIM) are presented. For the one-dimensional modeling, the River Habitat Simulation System (RHABSIM) was used to analyse the interaction between a water flow, the morphology of a riverbed, and the biological components of the environment. The habitat's hydroecological quality was evaluated after detailed ichthyological, topographical and hydro-morphological surveys. The main step was assessing the biotic characteristics of the habitat through the suitability curves for the Brown trout (Salmo trutta m. fario). Suitability curves are a graphic representation of the main biotic and abiotic preferences of a microhabitat's components. The suitability curves were derived for the depth, velocity, fish covers and degree of the shading. For evaluating the quality of the aquatic habitat, 19 fish covers were closely monitored and evaluated. The results of the Weighted Usable Area $(W U A=f(Q))$ were evaluated from a comprehensive assessment of the referenced reach of the Drietomica River.
Address

1 Department of Land and Water Resources Management, Faculty of Civil Engineering, Slovak University of Technology, Radlinského 11, 81368 Bratislava, Slovak Republic

Corresponding author: jana.jariabkova@stuba.sk

\section{Keywords}

- IFIM methodology,

- RHABSIM model,

- bioindication,

- Weight Usable Area (WUA).

\section{INTRODUCTION}

For an in-depth modeling of biological parameters, a systematic and repeatable analysis of the functioning of a stream is required. For such modeling, using models based on the principle of Instream Flow
Incremental Methodology (IFIM) is the standard in Europe (Bovee, 1982). The basis of the IFIM method is the River Habitat Simulation System (RHABSIM) developed in the USA; it is used for the analysis of the relationship between the stream and biotic components of an environment. This relationship is a continuous function of the flow 
(Milhous et al., 1989). RHABSIM optimizes the total pass of a fish based on the determination of the welfare of fish, depending on the flow and bed topography (Ordth, 1987).

The basic output of the RHABSIM model is the quantification of the abiotic parameters, which implicitly contain environmentally relevant testimony about the state of the biota in an aquatic area (Stalnaker, 1994). The RHABSIM program evaluates the Weight Usable Area (WUA) by individual cells, which are determined by the distribution of the cross sections. The next step is the characteristic of the biotic components of the habitat through the suitability curves of the fish species. For an objective evaluation, their identification is critical (Halaj, 2010). The most suitable part of the reference reach was selected on the Drietomica River to evaluate the WUA. A process to verify the suitability curves and the influence of the individual factors on the overall quality of the aquatic habitat of mountain streams in Slovakia was performed.

\section{CONTEXT}

\subsection{The characterization of the reference reach}

The Drietomica is a typical representative river in the Slovak flysch area and is located in northwestern Slovakia. The reference section of the Drietomica River was chosen because it contains various types of habitats, including fish covers. The reference section is $240 \mathrm{~m}$ long and lies above the village of Drietoma (Fig. 1). The character of the riverbed is natural with a segmented bottom. The riverbanks are stabilized by a root system of willow and alder vegetation, the crowns of which shade most of the stream. The average width of the riverbed is $5.5 \mathrm{~m}$ with $1 \mathrm{~m}$ deep local potholes. The mean grain gauge is $d_{50}$ $=26 \mathrm{~mm}$. The water of the Drietomica River belongs to class I of cleanness according to the oxygen regime factor; according to other factors, it belongs to class II.

\subsection{Assessment of the quality of the aquatic habitat}

The following procedures were used for modeling the quality of the aquatic habitat of the reference section of the Drietomica during the years 2004, 2005, 2006 and 2011:

- Measurements of the topographical parameters of the reference reach.

- Hydrometric measurements within 4 various water levels and 4 various discharges.

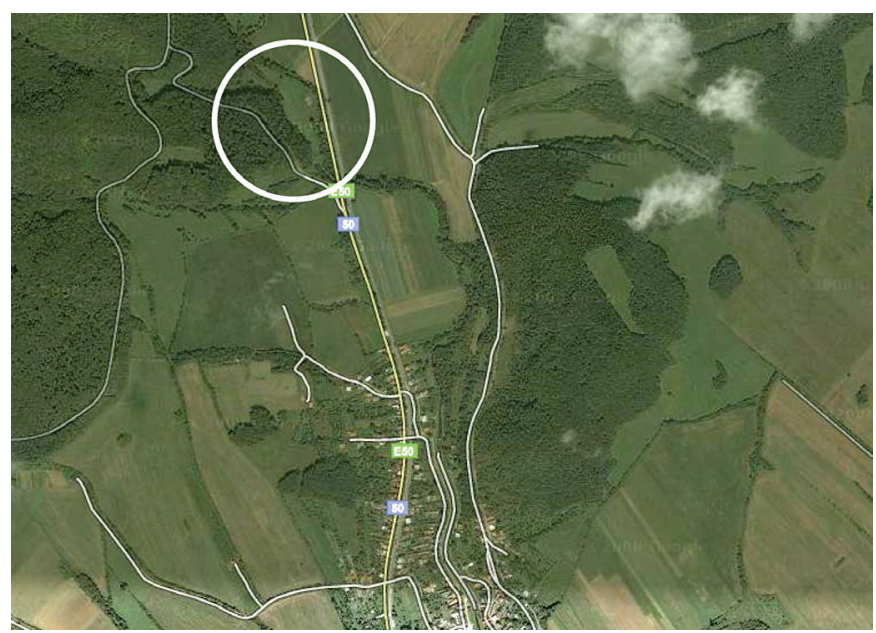

Fig. 1 Location of the reference section of the Drietomica River (origin: Google Earth).
- Conducting an ichthyological and hydraulic survey aimed at assessing the quality of the aquatic habitat for brown trout (Salmo trutta $\mathrm{m}$. fario), i.e., the determination of the suitability curves for the depth, velocity and fish covers.

- Processing the data that characterizes the individual types of microhabitats and suitability curves; quantification of the hydraulic and morphological characteristics of the stream using the Brown trout as a bioindicator.

\subsection{The ichthyologic measurements}

The ichthyologic measurements were implemented in cooperation with the Zoological Institute of the Slovak Academy of Science in Bratislava and the Department of Poultry Farming and Small Farm Animals of the Slovak Agricultural University in Nitra. For evaluating the quality of the aquatic habitat, 19 fish covers preferred by brown trout were closely monitored and evaluated.

\subsection{The suitability curves}

The suitability curves for the Brown trout are the basic characteristics of the aquatic habitat (depth - Fig. 2, velocity - Fig. 3) refilled by the indices, which reflect the action of other factors such as shading, the influence of the riparian vegetation, and the material of the microhabitat. Various types of habitats are represented by values in the form of indices, which indicate the degree of the preference of the factor by a bioindicator, in our case, the Brown trout (Salmo trutta $m$. fario). Suitability curves for velocity and depth are continuous. The cover suitability curves have the shape of a histogram, where the highest degree of suitability is equal to 1 . The relevant codes of all the types of the microhabitats are classified into the cover suitability histogram presented in Fig. 4.

\subsection{The Weight Usable Area}

The quantification of the quality of a habitat in the IFIM methodology is represented by the Weighed Usable Area (WUA). It is a direct function of any discharges and represents the suitability of the entire modeled reach divided into microhabitat levels. These outcomes are the proper basis for future decision-making and the water management process.

\section{METHODS}

The modeling of the three parameters (depth, velocity and cover) for the 30 (cs31 to cs61) cross sections (covers VI - XI) was evalu-

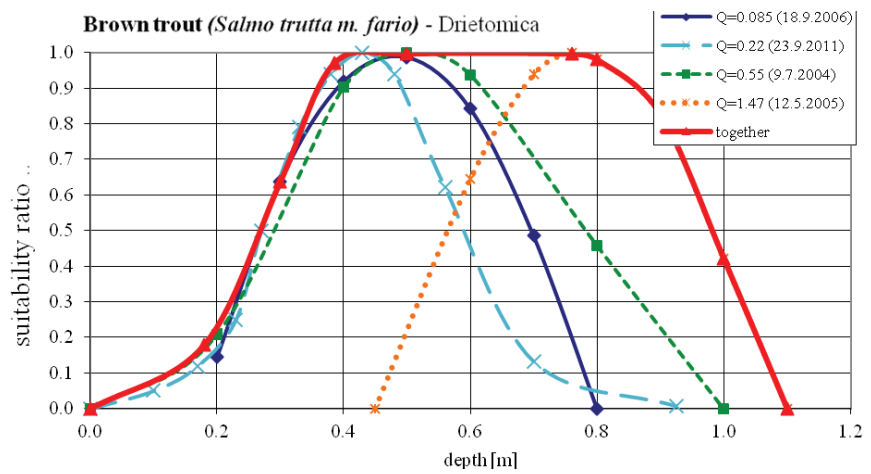

Fig. 2 Generalized suitability curve for the Brown trout (dark black line) for depth-for the years 2004, 2005, 2006 and 2011. 


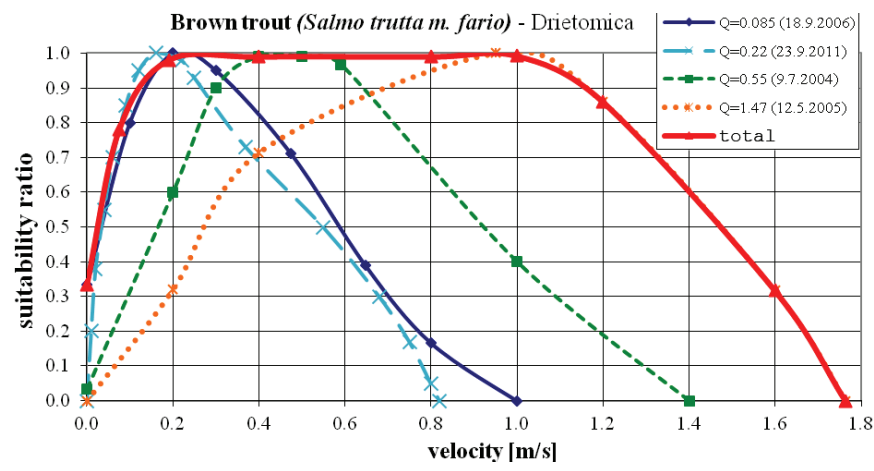

Fig. 3 Generalized suitability curve for the Brown trout (dark black line) for velocity - for the years 2004, 2005, 2006 and 2011.

ated in the RHABSIM model. Due to the topographical and ichthyological survey, the cs 31 to cs61 cross sections are the most suitable part of the reference reach for modeling the quality of the aquatic habitat (Tab. 1). For modeling and analyzing the interaction between the discharges, the morphology of the riverbed, and the different microhabitats as the biological components of the environment, the RHABSIM model was used. During the years 2004, 2005, 2006 and 2011, 19 covers of the reference section of Drietomica River were recorded and monitored; they are comprised of the following types of microhabitats (see Fig. 4):

- Deadwood (code 1)

- Macrophytes (code 2)
Microhabitat preferences by Brown trout (Salmo trutta $m$. fario) and suitability ratio (average for 2004/5/6/11)

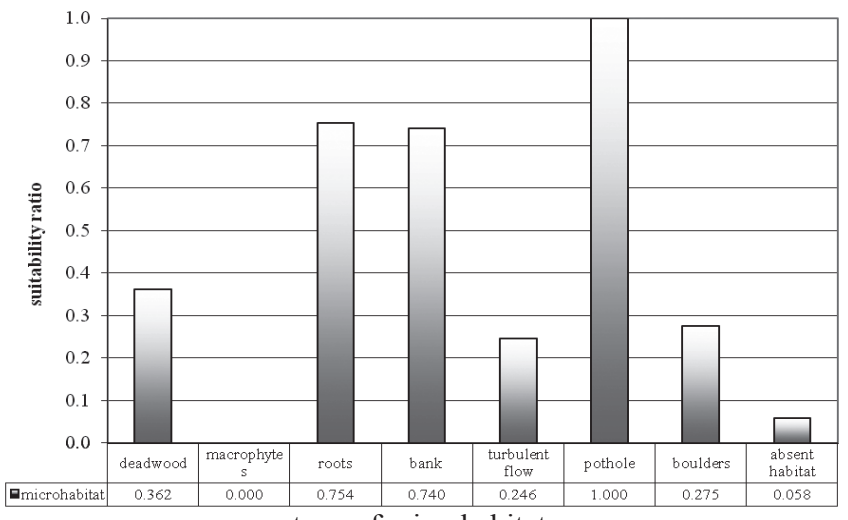

type of microhabitat

Fig. 4 Histogram with the microhabitat preferences indicated by the Brown trout (Salmo trutta $m$. fario) and suitability ratio (average for the years 2004, 2005, 2006 and 2011).

- Roots (code 3)

- Banks (code 4)

- Turbulent flows (code 5)

- Potholes (code 6)

- Boulders (code 7)

- Absent cover (code 8)

Tab. 1 Basic data of the Brown trout in the covers of the reference section of the Drietomica River during the years 2004, 2005,2006 and 2011.

\begin{tabular}{|c|c|c|c|c|c|}
\hline Cover type / number & $\begin{array}{c}\text { Number of units } \\
2004 \\
Q=0.55 \mathrm{~m}^{3} . \mathrm{s}^{-1}\end{array}$ & $\begin{array}{c}\text { Number of units } \\
2005 \\
Q=1.48 \mathrm{~m}^{3} \cdot \mathrm{s}^{-1}\end{array}$ & $\begin{array}{l}\text { Number of units } \\
2006 \\
Q=0.085 \mathrm{~m}^{3} \cdot \mathrm{s}^{-1}\end{array}$ & $\begin{array}{c}\text { Number of units } \\
2011 \\
Q=0.22 \mathrm{~m}^{3} . \mathrm{s}^{-1}\end{array}$ & $\begin{array}{c}\text { SUM } \\
2004,2005,2006, \\
2011\end{array}$ \\
\hline$A-I$ & 1 & 2 & - & 1 & 4 \\
\hline$A-I I / 1$ & 3 & 2 & - & 2 & 7 \\
\hline B - II/2 & 2 & - & - & - & 2 \\
\hline B - III & - & - & - & 1 & 1 \\
\hline$A-I V / 1$ & 2 & 1 & - & 4 & 7 \\
\hline$A-I V / 2$ & 5 & 1 & - & 5 & 11 \\
\hline$A-V / 1$ & 2 & - & - & 4 & 6 \\
\hline$A-V / 2$ & 2 & 1 & - & - & 3 \\
\hline$A-V I$ & 4 & 3 & 4 & 3 & 14 \\
\hline B- VII/1 & 1 & - & - & 2 & 3 \\
\hline B -VII/2 & 3 & - & - & 2 & 5 \\
\hline B -VIII & 2 & - & - & - & 2 \\
\hline$A-I X$ & 1 & 2 & - & 3 & 6 \\
\hline$A-X$ & 4 & 2 & 2 & 4 & 12 \\
\hline$A-X I$ & 9 & 2 & 1 & 6 & 18 \\
\hline$A-X I I$ & 1 & - & - & 1 & 2 \\
\hline A-XIII/1 & 2 & - & - & 3 & 5 \\
\hline A $-X I I I / 2$ & 2 & 1 & 2 & - & 5 \\
\hline A - XIV & 1 & 2 & 2 & 2 & 7 \\
\hline $\begin{array}{l}\text { Sum } \\
\text { Absent cover }\end{array}$ & $\begin{array}{c}52 \\
0\end{array}$ & $\begin{array}{c}19 \\
0\end{array}$ & $\begin{array}{c}11 \\
0\end{array}$ & $\begin{array}{c}43 \\
4\end{array}$ & $\begin{array}{c}120 \\
4\end{array}$ \\
\hline
\end{tabular}




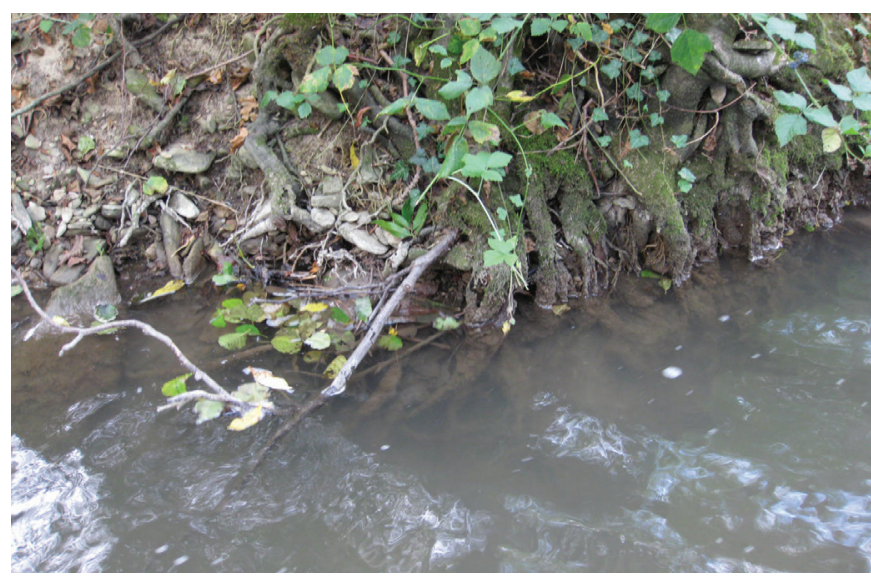

Fig. 5 Unexposed cover type A-VI formed by a roots system with dark and unexposed areas.

As an additional condition of the types of microhabitats, a different ratio of the sun-exposed covers was selected. On the reference reach of the Drietomica River, we defined two groups of covers as $\mathrm{A}$ and $\mathrm{B}$ :

A - covers especially constructed of the root systems of riparian vegetation, which create dark and unexposed areas - caverns used by ichthyofauna as a microhabitat or covers under deadwood, cavities in banks, respectively, between boulders (Fig. 5)

B - sun-exposed covers - places with solar contact. Covers, which are usually formed by a substrate bed, while the root system is located above the water level or not present at all (Fig. 6)

The most suitable part of the reference section (covers VI - XI) was selected on the Drietomica River to evaluate the WUA. In table 2, covers VI - XI (cs31 to cs61) are described. In this part of the reference section a suitability ratio for the unexposed cover $\mathrm{A}$ or the exposed cover B for the Brown trout (Salmo trutta m. fario) was evaluated (Fig. 7).

\section{RESULTS AND DISCUSSION}

The Riverine Habitat Simulation System (RHABSIM) was used to analyse the interaction between discharges, the morphology of a riverbed and the biological components of the environment. After a hydraulic calibration was performed, the available fish habitat in the shape of a weighed usable area was simulated using the RHABSIM model.

The results show that the depth and velocity significantly increase with the increasing of the flow. The quality of the aquatic habitat for

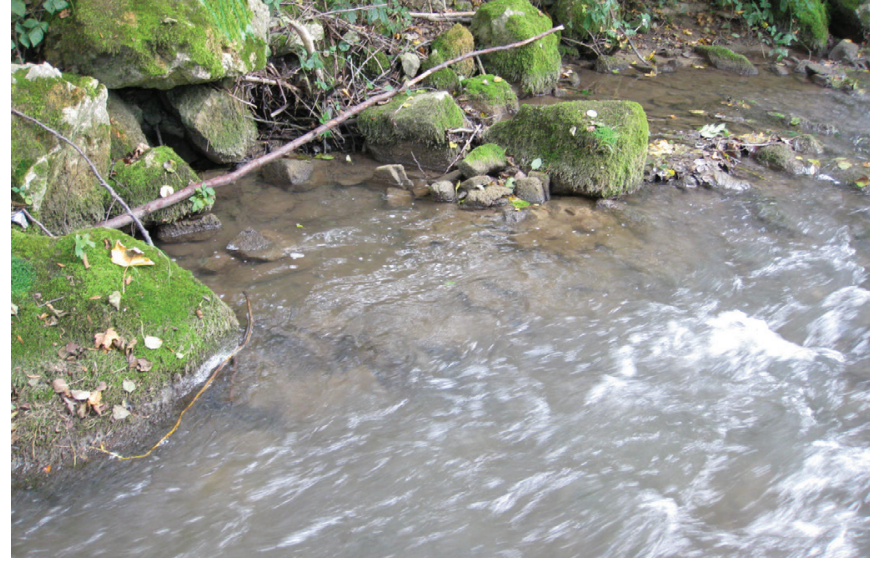

Fig. 6 Exposed cover type B - VIII formed by a bed substrate.

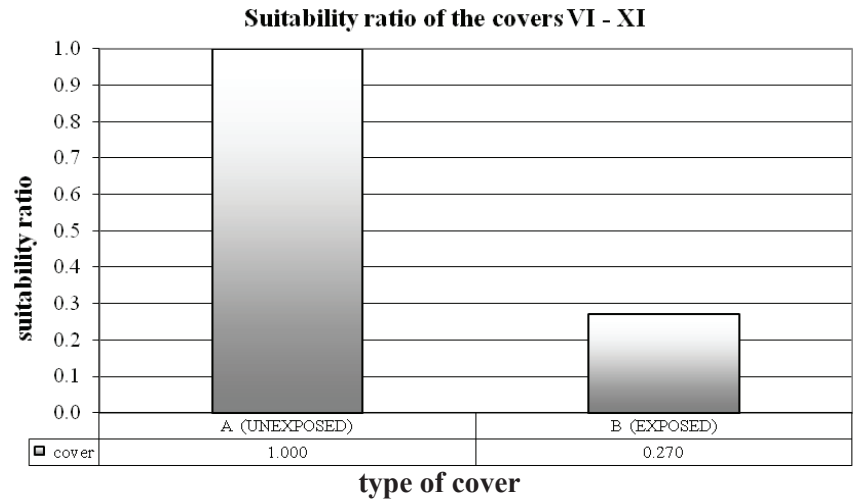

Fig. 7 Suitability ratio of the covers VI-XI as an A or B cover type.

the velocity parameters starts to improve when the flow reaches $Q=0.2$ $\mathrm{m}^{3} \cdot \mathrm{s}^{-1}$, and this trend of high suitability continues up to $\mathrm{Q}=3 \mathrm{~m}^{3} \cdot \mathrm{s}^{-1}$ (Fig. 8 - the red cells). The values of these flows correspond with the velocities from 0.2 up to $1 \mathrm{~m} \cdot \mathrm{s}^{-1}$. For flows higher than $\mathrm{Q}=3 \mathrm{~m}^{3} \cdot \mathrm{s}^{-1}$, the velocities are higher than $1 \mathrm{~m} \cdot \mathrm{s}^{-1}$, and the quality of the aquatic habitat is then reduced (Fig. 9 - the black cells). The microhabitats are then unacceptable for Brown trout; they will therefore search for a habitat with lower velocities.

During minimum flows, velocity is not the most important factor. The presence of depths, microhabitats, and fish covers as limiting factors for brown trout are decisive. The output of the RHABSIM model in Figure 10 is a suitability ratio for the minimum flow $Q=0.085$ $\mathrm{m}^{3} \cdot \mathrm{s}^{-1}$ (corresponding to $\mathrm{Q}_{365}=0,083 \mathrm{~m}^{3} \cdot \mathrm{s}^{-1}$ ), where as on the left figure for suitability of depth, the purple colour shows the cells with an unsuitable habitat (= unsuitable depth indicated by the brown trout). On the right figure for cover suitability, a strong correlation

Tab. 2 Description of the covers VI-XI (cs31 to cs61).

\begin{tabular}{|c|c|c|c|c|c|}
\hline $\begin{array}{l}\text { Cross } \\
\text { section }\end{array}$ & $\begin{array}{l}\text { Point } \\
\text { on the bank }\end{array}$ & $\begin{array}{l}\text { Cover type / } \\
\text { number }\end{array}$ & Cover description & Tree species & $\begin{array}{l}\text { Exposed / Unex- } \\
\text { posed }\end{array}$ \\
\hline $\operatorname{cs} 31-36$ & Right & $A-V I$ & A - cover formed by roots & Alder & unexposed \\
\hline $\operatorname{cs37-39}$ & Left & $\mathrm{B}-\mathrm{VII} / 1$ & B - cover formed by bed substrate & & exposed \\
\hline cs40-42 & Right & $B-V I I / 2$ & B - cover formed by bed substrate & & exposed \\
\hline $\operatorname{cs} 43-47$ & Left & $B-V I I I$ & B - cover formed by bed substrate & & exposed \\
\hline $\operatorname{cs} 48-52$ & Right & $A-I X$ & A - cover formed by roots & Shrubs & unexposed \\
\hline $\operatorname{cs53-57}$ & Right & $A-X$ & A - cover formed by roots & Alder & unexposed \\
\hline $\operatorname{cs58-61}$ & Right & $A-X I$ & A - cover formed by roots and deadwood & Willow & unexposed \\
\hline
\end{tabular}




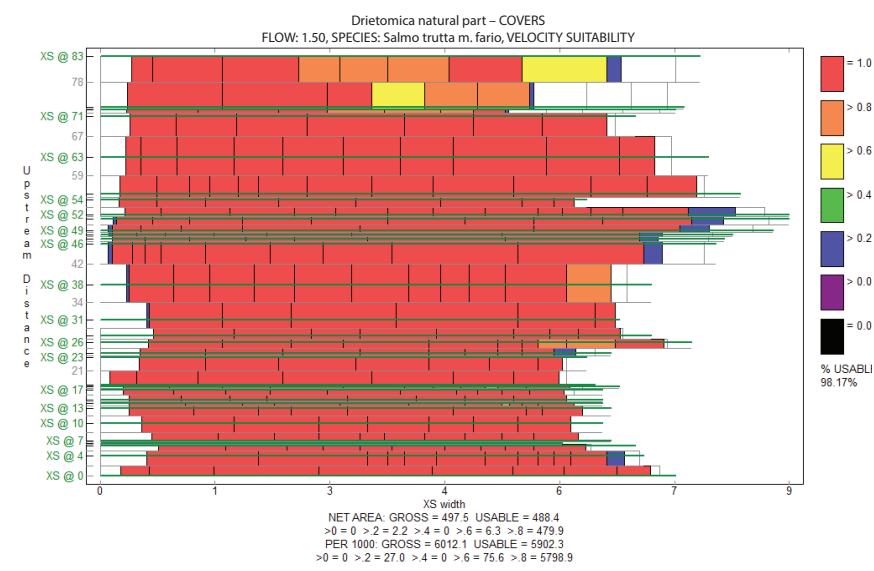

Fig. 8 Suitability of velocity for the Brown trout on the Drietomica River (presented area: $\operatorname{cs} 31$-cs61) for flow $Q=1.5 \mathrm{~m}^{3} \cdot \mathrm{s}^{-1}$.

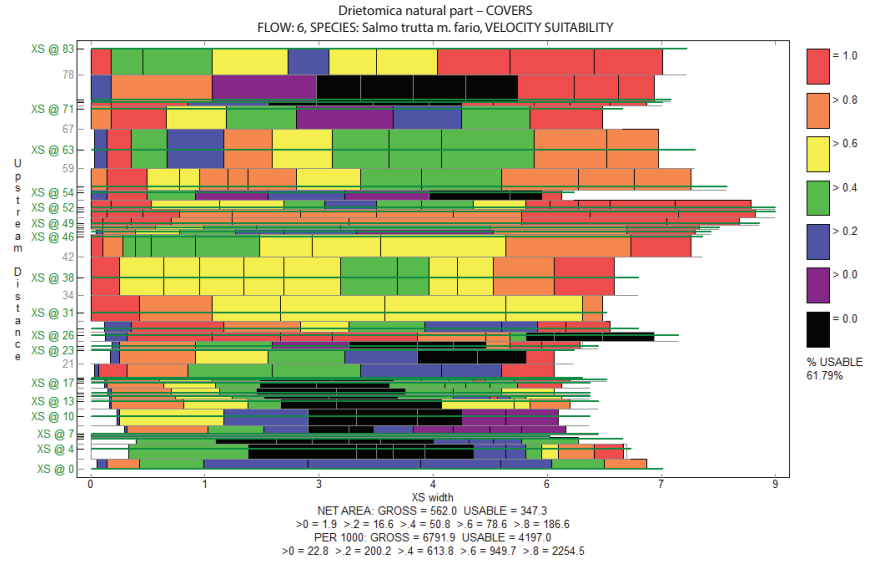

Fig. 9 Suitability of velocity for the Brown trout on the Drietomica River (presented area: cs31-cs61) for flow $Q=6 \mathrm{~m}^{3} \cdot \mathrm{s}^{-1}$.
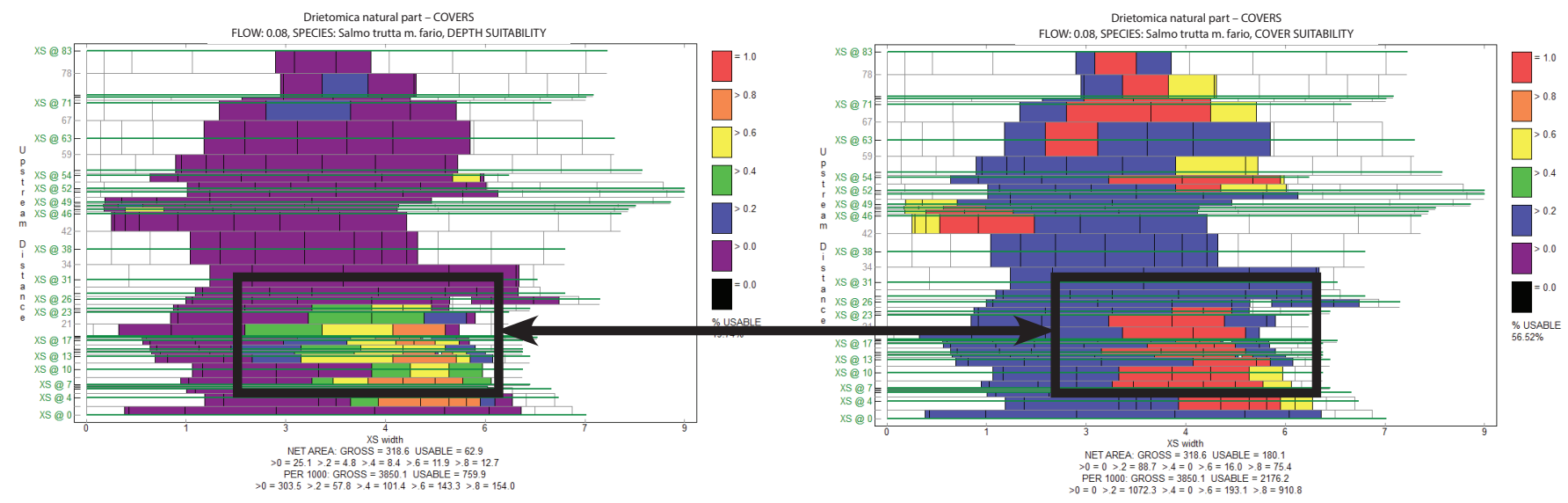

Fig. 10 Depth and cover suitability for the Brown trout on the Drietomica reach (presented area: $\operatorname{cs} 31$-cs61) for minimum flow $Q=0.085 \mathrm{~m}^{3} . \mathrm{s}^{-1}$.

between the depth and covers is shown. It follows that during minimum flows, Brown trout will prefer covers with maximum depths. The depth parameter also increases with an increasing flow, until it reach a flow with unsuitable velocities in the covers, and the fish will be forced to find another habitat. From these results it can be concluded that a suitability curve should be derived for the minimum flow, and its relevance will last until the time when the fish are forced to search for another habitat because of the higher speeds.

The results of the Weighted Usable Area (WUA $=\mathrm{f}(\mathrm{Q})$ ) was evaluated for the total area of the fish cover (AREA), the area of the cover (COVER), and the free surface (FREE). The Brown trout belongs among fish species which prefer habitats with covers and microhabitats that are usually shaded with bank vegetation. Figure 11 shows the output from the RHABSIM model for the unexposed fish cover VI. The red cells represent the cover (highest suitability); the blue cells represent the free surface (low suitability), and the total cover area is defined by 6 cross sections (AREA).

The quality of an aquatic habitat determines the suitability of a cover, where the biota is concentrated during extreme conditions of minimum flows. During this period the free surface area does not create favourable conditions for biota and should not be used for evaluating the WUA or for modeling the quality of the aquatic habitat. Only the cover area itself should be objectively evaluated, since it creates good conditions for the biota. The results presented in Figure 12 show the percentage of the WUA for the total area of the fish cover (AREA), the cover area (COVER) and the free surface area (FREE).

\section{CONCLUSION}

From previous research on the selected river in Slovakia, it can be seen that the relationship between a fish population and habitat characteristics reflect changes caused by a river bed's topography, flow and microhabitat structure - the presence of fish covers. The first results are also important, in that they point to the fact that it is not necessary to model the entire area of a reach (stream), but it is im-

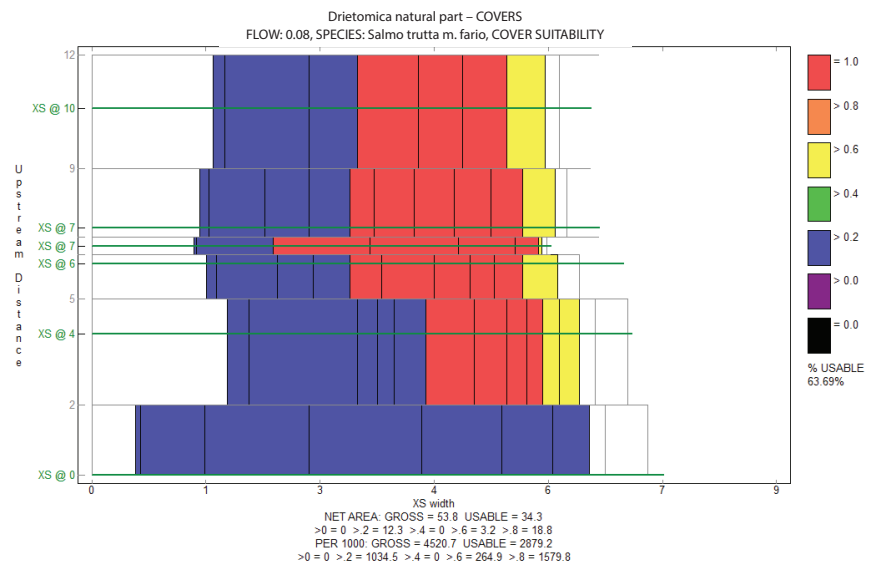

Fig. 11 Cover suitability for the Brown trout on the Drietomica River/section cover VI for minimum flow $Q=0.08 \mathrm{~m}^{3} . \mathrm{s}^{-1}$. 


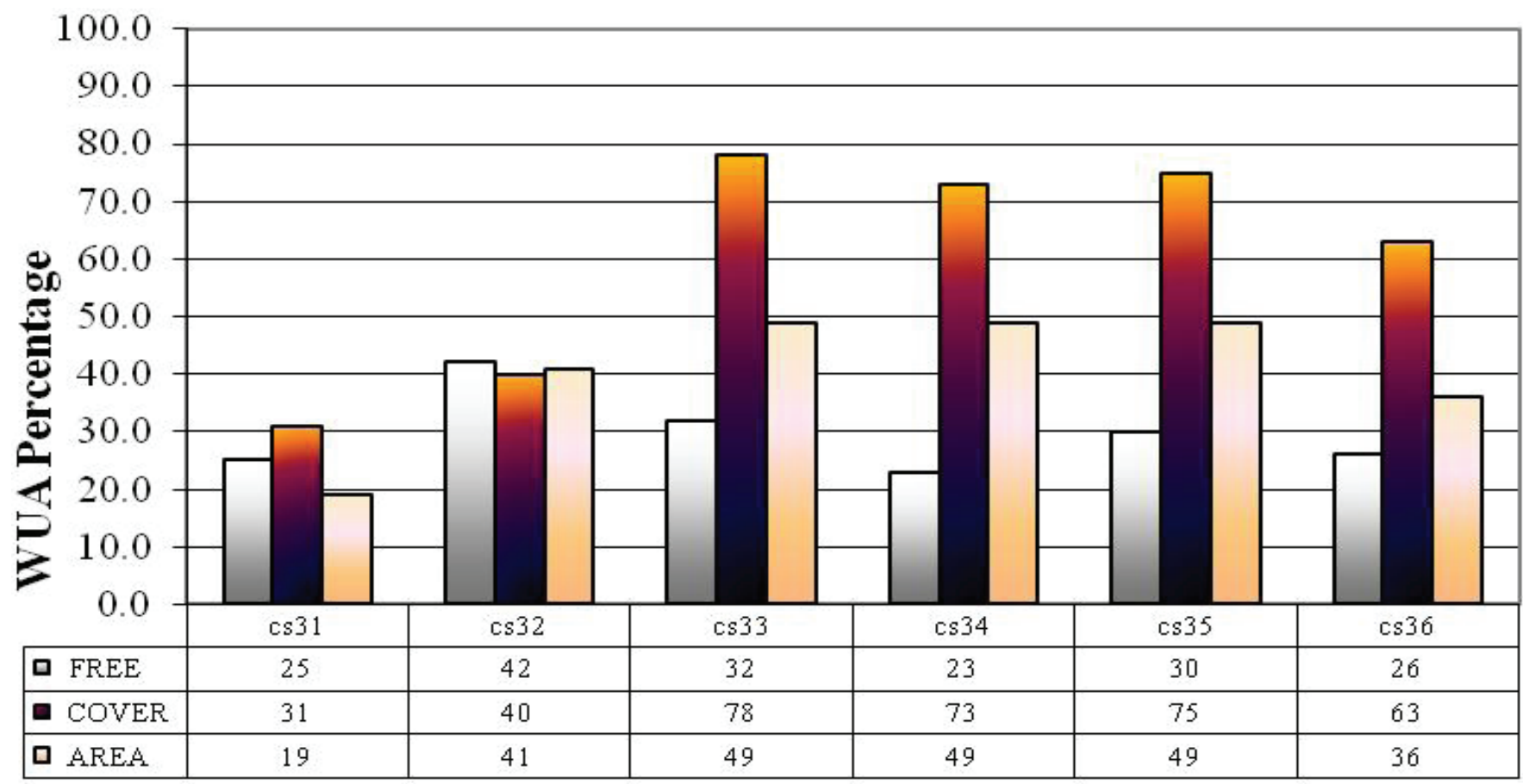

Fig. 12 WUA percentage for the Brown trout evaluated in cover VI.

portant to focus on the areas that accumulate biota during minimum flows. The quality of these areas is essential for achieving a good ecological status of the streams.

\section{Acknowledgements}

We are grateful for the support from Project No. VEGA $1 / 0243 / 11$, Influence of biotic and abiotic characteristics of a stream on the ecosystem and water regime of soils, and Project No. VEGA $1 / 1044 / 11$, Evolutionary algorithms and data-driven models in the water management of a country.

\section{REFERENCES}

Bovee, K. D. (1982) A guide to stream habitat analysis using the instream flow incremental methodology. Instream Flow Information Paper 12, Colorado: United States Fish and Wildlife Service, 248 pp.

Halaj, P. - Božoň, V. (2010) Súčasné prístupy k návrhu úprav korýt vodných tokov (Recent approaches to a stream regulation proposal). Slovak University of Agriculture in Nitra, Nitra, pp. 120 [in Slovak].

Milhous, R. T. - Updike, M. A. - Schneider, D. M. (1989) Physical Habitat Simulation System Reference Manual Version II. Instream Flow Information Paper No 26 National Ecology Research Center, Fish and Wildlife Service, U.S. Department of the Interior.
Ordth, D. J. (1987) Ecological considerations in the development and application of instream flow habitat models. Regulated Rivers: Research \& Management, vol. 1, pp. 171-181.

Stalnaker, C.B. (1994) Evolution of instream flow habitat modeling. In: Calow, P. - Petts, G.E. (eds.) The rivers handbook: hydrological and ecological principles. Oxford: Blackwell Scientific 2, pp. $276-286$. 